DOI: https://doi.org/10.47405/mjssh.v6i3.691

\begin{tabular}{|c|c|}
\hline & Malaysian Journal of Social Sciences and Humanities (MJSSH) \\
\hline 32 & Volume 6, Issue 3, March 2021 \\
\hline 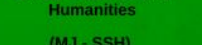 & e-ISSN : 2504-8562 \\
\hline & $\begin{array}{l}\text { Journal home page: } \\
\text { www.msocialsciences.com }\end{array}$ \\
\hline
\end{tabular}

\title{
House Ownership among Middle-income Urban Society Revisited: Multi-dimensional Perspectives
}

\author{
Annuar Mohamed1, Nor Malina Malek' \\ ${ }^{1}$ Development Planning and Management Programme, School of Social Sciences, Universiti Sains Malaysia (USM) \\ Correspondence: Annuar Mohamed (nua_zie@yahoo.com)
}

\begin{abstract}
House is considered as basic needs for everyone besides food, clothing, educational and medication needs. Owning a desired house is part of life achievement that ensures prosperous and productive way of living towards the society's well-being. The increasing population, rapid urbanization process and vast economic growth have contributed to the development of the housing sector in Malaysia. Numerous efforts were introduced by the government to ensure stability of housing ownerships within the society. However, not much attention was given to cater the housing needs of middle-income society especially in urban areas. This article revisits the house ownership issues faced by middleincome urban society based on challenges to own a house, impacts due to inability to own a house, and suggestions to increase the ability to own a house. A qualitative study using in-depth interview was conducted involving 15 informants selected among the middle-income society. Penang was chosen due to rapid economic growth, population, and urbanization rate. Data were analysed via content analysis method to discover the multi-dimensional themes. Study results indicated several multi-dimensional themes in terms of challenges, impacts and suggestions related to the issues such as economy, social, geography, physical, infrastructure and housing policies. This study main implication is to highlight the importance of multi-dimensional perspectives in solving the house ownership among middle-income urban society. It will contribute to the improvement of housing policies that fulfil the real needs of this group in owning a house for the well-being of the society.
\end{abstract}

Keywords: house ownership, middle-income, multi-dimensional perspectives, Penang, urban society

\section{Introduction}

House is one of the essential basic needs to human life not just as a place of shelter but also an important part in promoting well-being of a society. House ownership is considered as a crucial element in ensuring the safety of each individual and family as a place to live or for economic interest (Junaidi et al., 2020). The Sustainable Development Goal 11 stated that "by 2030, ensure access for all to adequate, safe and affordable housing and basic services and upgrade slum" (United Nations, 2015). Housing sector in Malaysia has evolved and grown rapidly overtime due to the increase of population, wider urbanization process and vast economic growth. Penang is one of the major cities contributing to Malaysia's economic growth with its' high density of population and expanding middle-income society in urban areas (Tash, 2015). Various housing policies were implemented for the society to increase the quality of life. However, those housing policies are more focused towards low-income society and neglecting the middle-income society especially in urban areas (Rosliana et al., 2020). Malaysia is 
among the developing countries that are facing the difficulties to provide the society particularly middle-income society with decent houses to be owned.

House ownerships remain as one of the difficult challenges faced by most of the developing countries in the 21st century (Ernawati et al., 2020). Concern is raised on the effectiveness of the existing housing policies that were initially meant to solve the increasing society's need to own a house. Nowadays, issues in house ownership are becoming more crucial for the middle-income society because this group of society are trapped between lower and high-income society resulting in the inability to own a house (Shahrizal et al., 2017). House ownership will significantly contribute to the overall well-being of the society and stabilize the economy of the nation. The ability of the urban society to own a house is influenced by various multi-dimensional factors that will have an impact towards the society's well-being (Nor Malina et al., 2017). Housing stress to own a house often been related to economic aspect, but in reality, there are other non-economic factors that may lead to the problem (Nooriah, 2019). This study was conducted to investigate the issues faced by middle-income urban society based on challenges to own a house, impacts due to inability to own a house, and suggestions to increase the ability to own a house from the multi-dimensional perspectives.

\section{Literature Review}

\section{Urban Developmentand House Ownership}

In general, the main objective of development is to increase the society's well-being by fulfilling all the basic needs and giving the opportunity to the society to enhance the standard of living (Nor Malina, 2019). The concept of development itself has gone through the transformation process in the aspect of its definition and philosophy since 1960's until 2000's. It started with the concept of economic growth, and later emphasized on distribution with growth, and further widen with the inclusion of social development (Abdul Rahman, 2018). Finally, development was being related with environmental conservation through the sustainable development concept along with human development concept (ul Haq, 1995) and development as freedom concept (Sen, 1999). An efficient urban development is important because it can be a catalyst in the nation's development process. Urban society's well-being will increase because the urban's quality of life is getting better and the human resources that move the development will be able to live comfortably and peacefully. It is concurrent with Goal 11 (SDG11) of Sustainable Development Goals (SDGs) that emphasizes on issues related to urban development by making cities and human settlements inclusive, safe, resilient, and sustainable.

Since independence, Malaysia had implemented numerous housing policies to solve the problem of house ownership. Malaysian government had never neglected the importance of house ownership within the society (Trofimov et al., 2018). The transition of the national housing policies since 1971 can be divided into 4 phases: housing for the poor (1971-1985), market reformation (1986-1997), squatters' eradication (1998-2011) and affordable house (2012 until present) (Syafiee, 2016). Efforts to bolster the affordable houses started during the 10th Malaysian Plan and continue to focus on the development of affordable houses under the 11th Malaysian Plan with various government agencies and department given the responsibility to implement the housing policies (Nor Baizura et al., 2016). The National Housing Policy highlighted the housing strategy guidelines for middle-income society with the collaboration from both public and private sectors (Rosliana et al., 2020). Housing provision for the society has always been the problem that raised doubts on the effectiveness of existing housing policies (Ernawati et al., 2020). Majority of the population are still craving for a comfortable, safe and affordable house. Households in the category of low and middle-income societies are still having difficulties to own houses according to the needs and financial capability. This shows that most of the housing development programs were just focussing on the affordability aspect while neglecting the sustainable aspect (Syed Jamaludin et al., 2018)

The current situation of urban development has seen the negative impact of development that has affect the society's quality of life, surroundings, and environment of urban areas (Nor Malina, 2019). Urbanization process and rapid growth of urban population have increased the middle-income 
population in urban area. The shortage of houses for middle-income society in urban area has become a critical issue in the context of urban development. Malaysia as a developing country is facing this situation with the increasing number of urban areas because of the rapid urban population and economic growth. The numbers of houses built for middle-income urban society are much lesser compared to high-cost houses (Nor Malina \& Azrina, 2012). The urgency to own a house among middle-income urban society is the main issue because of the inability to own a house is becoming more critical. The middle-income society is also not eligible to own a low-cost house offered based on the household income (Nooriah, 2019). Forming a more comprehensive housing policy is much needed because Malaysia is facing the increasing demand for affordable houses especially for the middleincome society (Rosylin et al., 2019).

\section{House Ownership in Penang}

Penang is no exception in the issue of house ownership with its population of 1.762 million people in the year 2018 compared to 1.561 million people in the year 2010 (Jabatan Perangkaan Malaysia, 2019) with its population density of 1.604 person per kilometre square (Penang Institute, 2016). Penang is among the top six states in Malaysia having it's Gross Domestic Product (GDP) per capita of 5.1\% above the national rate of $4.7 \%$ with manufacturing and services sectors being the main contributors (Jabatan Perangkaan Malaysia, 2019). Penang consistently recorded a high migration rate with the highest recorded at 4.4\% for the period between 2010 until 2011 (Jabatan Perangkaan Malaysia, 2012). With such high density of population, rapid economic growth and consistent migration rate, Penang is having problem in providing sufficient houses for all its population. The issue of urban housing is related to the insufficient supply of affordable houses that cannot meet the demand of the urban population (Nor Malina \& Azrina, 2012). It had caused the increase of the inability to own a house for low and middle-income society (MacDonald, 2012).

Penang is having the problem of limited space of land resources available in main urban areas as most of the lands available are owned by private developers which involved high-cost housing projects (Wan Nor Azriyati et al., 2018). Normal size of apartments available in Penang Island built by private developers is 850 square foot with cost of more than RM300,000.00. PR1MA housing program by the government are offering houses with size of 800 square foot until 1,400 square foot with valued cost between RM150,000.00 until RM300,000.00 (Nor Malina \& Azrina, 2012). The housing development are imbalance in providing houses for the society whereby affordable houses are less built compared to high-cost houses. In 2016, Penang recorded the highest median of 5.5 that falls under 'seriously unaffordable' and all properties launched are more than RM250,000.00, mostly ranging from RM500,000.00 until RM1,000,000.00, whereas median-3 house price is RM194,724.00 (Suraya, 2019). The government must ensure that houses built for middle-income urban society are sufficient in order to achieve sustainable development for the society's well-being.

\section{Multi-dimensionalAspectof House Ownership}

Sustainability in every dimension of urban development must be balanced between social needs, economy and environment for the benefit of the society (Dzul Ashari \& Hamzah, 2017). Housing is one of the main components in the aspect of quality of life and sustainable development. In determining the success of existing and future housing policies, various dimensions of well-being such as factors in social, economy, health and financial stability are among the critical indicators that must be evaluated (Rowley et al., 2015). Issues in housing ownership cannot be viewed in a single perspective, instead to include multi-dimensional perspectives (Hasniyati \& Nazari, 2018; Nor Malina et al., 2017). Findings from Dzul Ashari \& Hamzah (2017) summarized 9 themes from previous studies related to house ownership for the past 10 years shows other aspect apart from economic factors were highlighted but not done collectively. The themes mentioned are house cost, design, safety, public facilities, work distance, commercial area distance, public transportation distance, cleanliness, and neighbourhood. International organizations are recognizing the needs and understanding of housing affordability in a broader perspective, rather than evaluating based on simple ratio grounded on spending for house and income only (Mulliner \& Maliene, 2012). 
Most of previous studies are focussing on economic aspect as the main factor in influencing middleincome society to own a house (Eh Run \& Hairunnizam, 2017; Gholamreza et al., 2015; Hamidah \& Eleeza Eleena, 2016; Nor Baizura et al., 2016; Nor Malina \& Azrina, 2012; Norizan et al., 2016; Suhaida et al., 2011; Zainal Abidin, 2010). Meanwhile, recent studies also were done in relation to house ownership among middle-income society. According to Rosliana et al. (2020), ability to own a house within middle-income society cannot be viewed from just the economic aspect, instead house location near to workplace and comfortable space area must also be taken into consideration. Meanwhile, Junaidi et al. (2020) stated that household income is an important factor in influencing middle-income society to own a house suggesting control on the house price and better financial planning as the solution. Study conducted by Nooriah (2019) shows the quality of housing surroundings is affecting housing stress compared to economic factor. While these recent studies were by quantitative methods, a qualitative study by Ernawati et al. (2020) that conducts focus group discussion within the relevant stakeholders shows the need to redefine the price and review the term location in the concept of affordable houses. It can be concluded that studies on house ownership needed to be done continuously as currently it is an endless problem to the nation.

\section{Research Methodology}

This study was conducted using the qualitative approach and the data collection technique using the face-to-face in-depth interview. The purposive and snowballing sampling techniques were used as the sampling method. The scope of study is within the state of Penang covering urban areas such as George Town, Butterworth, Seberang Jaya and Bukit Mertajam. Penang was chosen because of its' highdensity population and urbanization rate among the highest in the country. This study targeted 30 participants as informants and the selection criteria were those with average monthly household income between RM2,614.00 until RM10,456.00 that either live or work in urban area. The income category is based on the definition of middle household income as stated in the 11th Malaysian Plan (11MP) Midterm Review Report (Kementerian Hal Ehwal Ekonomi, 2018). The interview process was discontinued after informant number 15 because the data obtained have reached its' saturation of themes in fulfilling the objectives of the study. Qualitative study does not set the sampling size but should be in a small number (Patton, 2015) with minimum of 10 participants (Creswell, 2014) taking into consideration it has reached its' data saturation (Slevitch, 2011). Furthermore, the sample size of 15 informants is adequate and representative as the number exceeding the general rule of thumb sample size between 5 and 25 interviews recommended of any qualitative study (Kvale \& Brinkmann, 2015). Qualitative data analysis technique is by content analysis method to obtain meaning of the contents in the form of contextual towards the texts. Data content analysis is executed systematically by forming themes and sub-themes through the content analysis process using thematic and domain analysis.

\section{Findings and Discussions}

Content analysis conducted systematically through thematic analysis and domain analysis (sub-themes with the most frequency for each theme) towards the data collected from the informants has resulted in the formation of the thematic content analysis matrix shown in Schedule 1 below. Results from the thematic analysis shows that there are six themes or dimensions that are formed in order to meet the objectives of the study of identifying challenges to own a house, impacts due to inability to own a house, and suggestions to increase the ability to own a house. Five of the themes or dimensions existed in all the objectives of the study namely economic, social, geographical, physical, infrastructural and housing policy. The infrastructural dimension only applicable for the objective of identifying challenges to own a house. 
Malaysian Journal of Social Sciences and Humanities (MJSSH), Volume 6, Issue 3, (page 319 - 329), 2021

DOI: https://doi.org/10.47405/mjssh.v6i3.691

Schedule 1: Multi-dimensional Dimensions in House Ownership among Middle-income Urban Society

\begin{tabular}{|c|c|c|c|c|c|c|}
\hline \multirow{3}{*}{$\begin{array}{l}\text { Themes/ } \\
\text { Dimensions }\end{array}$} & \multicolumn{6}{|c|}{ Research Objectives } \\
\hline & \multicolumn{2}{|c|}{ Challenges to Own a House } & \multicolumn{2}{|c|}{$\begin{array}{c}\text { Impacts Due to Inability to } \\
\text { Own a House }\end{array}$} & \multicolumn{2}{|c|}{$\begin{array}{l}\text { Suggestions to Increase } \\
\text { Ability to Own a House }\end{array}$} \\
\hline & $\begin{array}{l}\text { Sub-themes/ } \\
\text { Domains }\end{array}$ & $\begin{array}{c}\text { Most } \\
\text { Frequent } \\
\text { (for each } \\
\text { theme) }\end{array}$ & $\begin{array}{l}\text { Sub-themes/ } \\
\text { Domains }\end{array}$ & $\begin{array}{c}\text { Most } \\
\text { Frequent } \\
\text { (for each } \\
\text { theme) }\end{array}$ & $\begin{array}{l}\text { Sub- } \\
\text { themes/ } \\
\text { Domains }\end{array}$ & $\begin{array}{c}\text { Most } \\
\text { Frequent } \\
\text { (for each } \\
\text { theme) }\end{array}$ \\
\hline Economic & $\begin{array}{l}\text { Financial } \\
\text { Commitment }\end{array}$ & 15 & $\begin{array}{l}\text { Financial } \\
\text { Standing }\end{array}$ & 10 & Income & 9 \\
\hline Social & $\begin{array}{l}\text { Option to Own } \\
\text { House }\end{array}$ & 14 & $\begin{array}{c}\text { Life } \\
\text { Sustainability }\end{array}$ & 15 & Awareness & 11 \\
\hline Geographical & Location & 14 & Location & 12 & Location & 2 \\
\hline Physical & $\begin{array}{c}\text { House } \\
\text { Specification }\end{array}$ & 12 & House Size & 4 & House Size & 1 \\
\hline Infrastructural & $\begin{array}{l}\text { Public } \\
\text { Facilities }\end{array}$ & 11 & - & - & - & - \\
\hline Housing Policy & $\begin{array}{l}\text { Qualification } \\
\text { Process }\end{array}$ & 6 & Development & 5 & $\begin{array}{l}\text { Revised } \\
\text { Policies }\end{array}$ & 15 \\
\hline
\end{tabular}

\section{Economic Dimension}

Result of the analysis found out that the economic dimension is one of the main dimensions when discussing the house ownership among middle-income urban society. The study concluded that financial commitment is the most frequent sub-theme for economic dimension under challenges to own a house. It basically means that an individual will have to choose in spending the income between nonhousing expenditures or housing expenditures. Choosing the expenditures will be a challenge to the middle-income urban society. As mentioned by informant \#5, a parliament coordinator in the following statement:

"We have to look at the problem that arises, it all depends on the issue of needs against affordability, meaning if other commitments are too high, then it will be quite difficult and a challenge to own a house."

Meanwhile, this study also found out that financial standing is the most frequent sub-theme for economic dimension under impacts due to inability to own a house. It very much depends on the affordability level of each person based on the financial standing. The consequences of unstable financial standing will be resulted in failing to own a house, at least not until the financial standing is stable. This statement is supported by informant \#9, an enforcement officer as stated below:

"It is a serious issue because each person will have a dream to own a house, but if the financial standing is not strong, then it will cause failure to own a house at that particular period of time."

As for the suggestions to increase the ability to own a house, the study shows that income is the most frequent sub-theme for economic dimension, Feedbacks from middle-income urban society indicated that financial resources of a person should be strengthen by supplementing the financial resources thus generating extra income. It will further facilitate in the quest to own a house. Informant \#11, an engineer explained the suggestion as per below statement: 
"I'm thinking of doing part time job in order to get extra income, for example I have started to do online business and I am also thinking going into stock and money exchange investment."

It is obvious that economic dimension is one of the important dimensions in discussing the issues of house ownership among middle-income urban society. The desire to own a house that fulfils the needs and wants will be achieved when the financial commitment does not affect the basic needs. A weakened financial standing will distort the ambition to own a house. However, pro-active efforts to earn extra income will ease the financial burden faced by middle-income urban society and later to own a house.

\section{SocialDimension}

From the study, it was found out that social dimension being mentioned in the issue of house ownership among middle-income urban society. As for challenges to own a house, result of the analysis shows that option to own a house as the most frequent sub-theme for social dimension. Option to own a house lays in the hand of the middle-income urban society whether to own a house now or later. This experience was shared by informant \#10, an immigrant officer as follows:

\section{"Due to fewer housing developments at my desired area, I took a longer period of time to own my own house. At the end, I decided to choose a house at Simpang Ampat, Tasek, SPS because that is the best option that I have at that time."}

Study result also shows that life sustainability is the most frequent sub-theme for social dimension under impacts due to inability to own a house. The main factor related to life sustainability in urban area is having a place to live as a place to stay, rest and sleep. Due to the inability to own a house in urban area, middle-income society will tend to rent a house in order to survive the urban style of living. It is further explained by informant \#6, a chief security as stated below:

"I myself experience the impacts in the efforts to own my own house and due to the inability to own a house; I have been renting a house for more than 5 years now and pay monthly rental payment of RM750.00 per month."

Furthermore, under suggestions to increase the ability to own a house, data analysis shows that awareness is the sole sub-theme for social dimension. Awareness refers to having the knowledge of the importance of owing a house and efforts to own a house by adapting the culture of saving and spending wisely in the daily expenditures. This statement was supported by informant \#7, an administration officer as per below statement:

"Middle-income society must have the awareness to own a house within a realistic time period. The awareness must be in the early stages, for example I was always taught by my parents since my younger days the importance of savings."

Middle-income society will always have the option and freedom to choose from various choices and alternatives to own a house. Those unable to own a house will have no choice but to rent a house for survival purposes. Problem of inability to own a house can be solved by promoting the awareness at home, school or even by the government.

\section{GeographicalDimension}

This study also identified geographical dimension as one of the dimensions in house ownership among middle-income urban society. Furthermore, data analysis shows that location is the sole sub-theme under geographical dimension for all of the objectives of the study. In terms of challenges to middleincome urban society to own a house, a strategic location of the house has always been the top priority. Informant \#13, an insurance agent further elaborates on this matter as per his statement below: 
"The importance thing for me is the location; I have bought a house at Bayan Lepas in 2015, and my criteria owning that house because it is situated at a strategic location with the town area."

Meanwhile, the impacts due to inability to own a house among middle-income urban society is that having to own a house in location outside the preferred strategic location in sub-urban or rural areas. This situation is faced by informant \#15, a human resource officer having to own a house at a location in Seberang Perai due to his constraint to own a house at his preferred location in Penang Island. His statement is as follows:

"I originated from Penang Island, and I prefer to own a house at that area. But, with my situation of just working in the public sector, I am not able to own a house at Penang Island, and then I decided to own a house in Seberang Perai."

In terms of suggestions to increase the ability to own a house, findings from the study suggested that middle-income urban society will need to search for houses to be owned in a location outside the strategic urban areas. The distance might be the disadvantage, but the advantage the ability to own a more comfortable and spacious house. This view is shared by informant \#1, an administration officer with his statement as per below:

"The reality is that in Penang island, with the cost of RM300,000.00, we will only be able to own an apartment. Instead, if we insist to own a house with the same price but having higher specification, then we should opt for outside island area."

Owning a house at a preferred strategic location will be a difficult challenge to overcome. Difficulties in owning a house at the preferred location will divert the attention to own a house at alternative locations. Therefore, it is much better to own a house at a location at sub-urban or rural area to enable owning a house worth the value.

\section{PhysicalDimension}

This study also revealed physical dimension is another multi-dimensional perspective in house ownership among middle-income urban society. Data analysis shows that house specification is the sole sub-theme for physical dimension under challenges to own a house. House specification refers to criteria of a house that is able to attract the society such as design, size area, material, accessories facilities and other types of specification needed to build a house. It is usually related with the cost of building a house. This is supported by informant \#8, an entrepreneur as per below statement:

"Obviously, there is a big difference in terms of specification of a house between island area and mainland area considering that the house price is the same cost between these two areas".

Subsequently, this study also found out that house size is also the sole sub-theme for physical dimension under impacts due to inability to own a house. The inability to own a house with the desired house size may result in either owning a smaller house in urban areas or a bigger house outside urban areas. The experience of informant \#12, a researcher with regards to the issue is a very good example of the situation. His explanation as below:

"Actually, I am interested in landed house located in Penang Island, but landed houses in Penang Island are way out of my reach. Therefore, I will have to do with the apartment type of house that is multi-storey and house with smaller size."

As for the suggestions to increase the ability to own a house, it was concluded that house size again is the sole sub-theme for physical dimension. Middle-income urban society is urging the government to 
be pro-active to restore existing housing area in urban area for the benefit of the society. This is highlighted by informant \#15 as stated below:

"I suggest the government to take over old flats or apartment owned by them, and rebuilt, renovate or restore such buildings and resize the built-up area equivalent to medium cost houses."

Houses that could provide a desired specification according to the needs will give satisfaction and comfortability to the society. The inability to own a house with the desired size, will resulted in medium income urban society to own a smaller house size or own a bigger house size outside urban area. Proper actions by the government are required to ensure that house size issues are effectively managed.

\section{InfrastructuralDimension}

Result of the analysis found out that infrastructural dimension is one of the multi-dimensional perspectives of the house ownership among middle-income urban society. The study also concluded that infrastructural dimension was categorized solely for the objective of challenges to own a house. Access to public facilities is the most frequent sub-theme for the infrastructural dimension. Public facilities refer to facilities surrounding the housing area such as supermarket, hospital, school, fields, and halls, or specially used by house owners such as lift and parking facilities. Informant \#2, an assistant manager best described his house meeting the criteria as per statement below:

\section{"My house is an apartment located at Bayan Baru, a place nearby to Hospital Pantai, supermarkets, schools and other facilities for my convenience. The other criterion of my apartment is the spacious parking space allocated."}

Public facilities are considered important because it will provide safety and convenience to the housing population. The infrastructural dimension especially public facilities are very much needed by the society to ensure well-being of the society. Residents would have the convenience if public facilities are located near the housing area. Housing area complete with the public infrastructure and facilities supporting the urban society will represent an advance and dynamic urban area.

\section{Housing Policy Dimension}

This study highlighted that housing policy dimension is another multi-dimensional perspective in house ownership among middle-income urban society. Data analysis shows that qualification process is the most frequent sub-theme for housing policy dimension under challenges to own a house. Qualification process is becoming the main concern of middle-income urban society especially in selecting the most qualified house buyers for affordable house scheme by the government. It seems that there are flaws and bureaucratic practices in the selection process of applicants to be offered affordable houses. This statement is supported by informant \#14 as stated below:

"In terms of location, applicant who resides in Balik Pulau was offered a house at mainland area. The applicant will surely reject the offer because the application for a house at Balik Pulau."

Data analysis also shows that development is the sole sub-theme for housing policy dimension under impacts due to inability to own a house. The inability to own a house among middle-income society had proved that this issue was not taken seriously by the government. Only now that we can see the government is pro-actively taking necessary actions to ensure the houses for middle-income society are taken care off. Informant \#3, an assistant registrar further elaborated on this point as follows:

"The government is only concentrating on low-income society and neglecting the middleincome society. Nevertheless, we can see the efforts by the government through the PRIMA and PPIAM initiatives for the benefit of middle-income society." 
Meanwhile, study result shows that revising relevant policies are the most frequent sub-theme for housing policy dimension under suggestions to increase the ability to own a house. This study proved that the issue of house ownership was not studied in a comprehensive manner and concluded that the existing housing policy need to be revised and re-evaluate by the government. This is strongly supported by the statement from informant \#10 as below:

"The government should do a comprehensive research focussing on middle-income society in order to get a clearer understanding of the problems. It will definitely assist in formulating a complete housing policy in the near future".

Middle-income urban society has been frustrated by the qualification process of government housing program with the bureaucratic and non-transparent procedures. It has created problem of among this society to own a house especially in urban areas. It is further worsened with the housing policy implemented not favouring middle-income society although efforts are on the rise. Therefore, it is time for the government to re-evaluate and revise the existing housing policy to increase the ability in owning a house among middle-income urban society.

\section{Conclusion and Implications}

Numerous efforts are being implemented by the government to fulfill the society's housing needs through various housing related policies. They are concentrating more on low-income society, while middle-income society is being neglected. This has caused the issue of house ownership among middle-income urban society not being solved comprehensively These efforts also focus only on the economic dimension without taking other multi-dimension perspectives into consideration. This study is conducted to identify and analyse the challenges to own a house, impacts due to inability to own a house, and suggestions to increase the ability to own a house among the middle-income urban society in Penang. In summary, this study managed to find various multi-dimensional perspectives when discussing this issue namely the dimension of economic, social, geographical, physical, infrastructural and housing policy. The main implication of this study is emphasizing the importance of multidimensional perspectives in house ownership among middle-income urban society. It will enable the implementation of a much more effective housing policy to achieve society's well-being.

\section{References}

Abdul Rahman, E. (2018). Pembangunan dan kesejahteraan: agenda kemanusiaan abad ke-21. Bangi: UKM Press.

Creswell, J. W. (2014). Research design: qualitative, quantitative \& mixed methods approaches (4th ed.). Thousand Oaks: Sage Publications, Inc.

Dzul Ashari, A. B., \& Hamzah, J. (2017). Kesejahteraan komuniti dalam skop perumahan mampu milik mampan. Geografia: Malaysian Journal of Society and Space, 13(2), 97-114.

Eh Run, E. N., \& Hairunnizam, W. (2017). Gelagat tabungan dan tahap pengetahuan pembeli rumah terhadap proses kelayakan pembiayaan perumahan: kajian di Lembah Klang. In Prosiding Persidangan Kebangsaan Ekonomi Malaysi Ke-12 (pp. 1199-1209). Bangi: Penerbit UKM.

Ernawati, M. K., Kong, S. L., \& Nor'Aini, Y. (2020). The low-middle income housing challenges in Malaysia. Planning Malaysia: Journal of Malaysian Institute of Planners, 18(1), 102-117.

Gholamreza, Z., Mahadevan, S., Ayesha, A., \& Lai, K. T. (2015). The economic factors affecting residential property price: the case of Penang island. International Journal of Economics and Finance, 7(12), 200-210.

Hamidah, R. \& Eleeza Eleena, Z. (2016). Review the issue of housing among urban dwellers in Malaysia with special reference towards affordability to home ownership. Procedia Economics and Finance, 35, 216-223.

Hasniyati, H., \& Nazari, I. (2018). Pemilikan rumah bergadaijanji di Malaysia : isu dan solusi jangka masa panjang. Geografia: Malaysian Journal of Society and Space, 14(2), 26-40. 
Jabatan Perangkaan Malaysia. (2012). Corak dan trend migrasi di Malaysia. Statistik Rasmi Malaysia. Retrieved from https://www.dosm.gov.my/v1/

Jabatan Perangkaan Malaysia. (2019). Poket stats negeri Pulau Pinang. Statistik Rasmi Malaysia. Retrieved from https://www.dosm.gov.my/v1/

Junaidi, A. B., Siti Nor Isma', M. R., \& Rosniza Aznie, C. R. (2020). Faktor mempengaruhi pemilikan rumah dalam kalangan isi rumah berpendapatan sederhana. Akademika, 90(Isu Khas 1/ Special Issue), 115-127.

Kementerian Hal Ehwal Ekonomi. (2018). Kajian separuh penggal: Rancangan Malaysia kesebelas 2016-2020: keutamaan dan penekanan baharu. Kuala Lumpur: Percetakan Nasional Malaysia Berhad.

Kvale, S., \& Brinkmann, S. (2015). Interviews : learning the craft of qualitative research interviewing. Thousand Oaks: SAGE Publications.

MacDonald, S. (2012). Supply and Demand in the Penang Housing Market: Assessing Affordability. Penang Institute, (October), 1-36.

Mulliner, E., \& Maliene, V. (2012). What attributes determine housing affordability? International Journal of Social, Behavioral, Educational, Economic, Business and Industrial Engineering, 6(7), 1833-1838.

Nooriah, Y. (2019). Faktor penyumbang kepada tekanan perumahan di kawasan perumahan kos rendah dan sederhana rendah di Pulau Pinang. Kemanusiaan: The Asian Journal of Humanities, 26(1), 143-171.

Nor Baizura, J., Yusfida Ayu, A., \& Hazlina, H. (2016). Encapsulating the delivery of affordable housing: an overview of Malaysian practice. MATEC Web of Conferences, 66(00047), 1-8.

Nor Malina, M. (2019). Tadbir urus yang baik dalam perancangan dan pengurusan pembangunan bandar. In R. B. Radin Firdaus, S. L. Khoo, M. Nor Malina, \& M. S. Maslina (Eds.), Wacana multidimensi: dalam perancangan dan pengurusan pembangunan di Malaysia (pp. 87-99). Tanjong Malim: Penerbit UPSI.

Nor Malina, M., \& Azrina, H. (2012). Pemilikan rumah dalam kalangan masyarakat bandar berpendapatan sederhana dan rendah di Malaysia. Sosiohumanika, 5(2), 269-284.

Nor Malina, M., Mohamad Shaharudin, S., Khoo, S. L, Parthiban, S. G., \& Zahri, M. (2017). Kemampuan memiliki rumah dalam kalangan keluarga bandar di Malaysia. Geografi, 5(2), 6977.

Norizan, R., Dani, S., \& Mazlan, I. (2016). Kemampuan memiliki rumah: satu analisa dari sudut sosio-ekonomi isi rumah. Malaysian Journal of Social Sciences and Humanities, 1(1), 10-16.

Patton, M. Q. (2015). Qualitative evaluation and research methods (4th ed.). Thousand Oaks: Sage Publications.

Penang Institute. (2016). Buku data asas sosio-ekonomi negeri Pulau Pinang. Pulau Pinang: Pejabat SUK Negeri Pulau Pinang.

Rosliana, M., Zaimah, R., \& Sarmila, M. S. (2020). Kemampuan pemilikan rumah dalam kalangan M40 di Malaysia. Akademika, 90(Isu Khas 1/ Special Issue), 63-74.

Rosylin, M. Y., Shazida Jan, M. K., Fauziah, M. Y., \& Nurul Huda, A. M. (2019). Bridging the supply and demand gap for affordable home ownership in Malaysia: the roles of government and financial institutions. Planning Malaysia: Journal Of Malaysian Institute of Planners, 7(1), 160175.

Rowley, S., Ong, R., \& Haffner, M. (2015). Bridging the gap between housing stress and financial stress: the case of Australia. Housing Studies, 30(3), 473-490.

Sen, A. (1999). Development as freedom. New York: Alfred A. Knopf.

Shahrizal, A. S., Nooraini, O., Nor Ashikin, M. Y., \& Zamri, M. (2017). Preliminary review on housing policy and its implementation in Malaysia. Journal of Science, Technology and Innovation Policy, 3(1), 30-33.

Slevitch, L (2011). Qualitative and quantitative methodologies compared: ontological and epistemological perspectives. Journal of Quality Assurance in Hospitality and Tourism, 12(1), 73-81.

Suhaida, M. S., Tawil, N. M., Hamzah, N., Che-Ani, A. I., Basri, H., \& Yuzainee, M. Y. (2011). Housing affordability: a conceptual overview for house price index. Procedia Engineering, 20, $346-353$. 
Suraya, I. (2019). Agenda perumahan: peranan kerajaan, pasaran dan masyarakat. Kuala Lumpur: Khazanah Research Institute.

Syafiee, S. (2016). The housing provision system in Malaysia. Habitat International, 54, 210-223.

Syed Jamaludin, S. Z. H., Mahayuddin, S. A., \& Hamid, S. H. A. (2018). Challenges of integrating affordable and sustainable housing in Malaysia. In IOP Conference Series: Earth and Environmental Science 140 (pp. 1-8).

Tash, A. W. (2015). What Middle Class Means in Malaysia. The New York Times. Retrieved from https://www.nytimes.com/2015/11/19/opinion/what-middle-class-means-in-malaysia.html?_r=0

Trofimov, I. D., Nazaria, M. A., \& Xuan, D. C. D. (2018). Macroeconomic and demographic determinants of residential property prices in Malaysia. Zagreb International Review of Economics and Business, 21(2), 71-96.

ul Haq, M. (1995). Reflections on human development. New York: Oxford University Press.

United Nations. (2015). Transforming our world: the 2030 agenda for sustainable development. New York: UN.

Wan Nor Azriyati, W. A. A., Noor Rosly, H., Ainoriza, M. A., \& Mahazril'aini, Y. (2018). Housing policy in Malaysia: bridging the affordability gap for medium-income house. In H. C. Rebecca Lai \& H. Seong-Kyu (Eds.), Housing policy, wellbeing and social development in Asia (pp. 141-156). Oxon: Routledge.

Zainal Abidin, H. (2010). House price and affordability in housing in Malaysia. Jurnal Akademika, 78, $37-46$. 